\title{
RECORDS OF FLEAS FROM THE AUSTRIAN TIROL AND THE DOLOMITES.
}

\author{
BY DR. KARL JORDAN. \\ (With one text-figure.)
}

THE weather being on the whole unfavourable, I was not very successful with trapping at Moserboden, a charming high alpine "Moos" above Zell am See, where we stayed nearly a fortnight in spite of rain and snow, in August 1930. I had hoped to discover the male of Ctenophthalmus nivalis dolomiticus, peculiar to the Snowmouse, but, as in the Dolomites, I obtained only a few females. There was little on the mice at Moserboden, a large percentage of the mice yielding nothing, even among those caught alive, which was quite contrary to my previous experiences in the Alps. No fleas having been recorded from the Hohe Tauern district, I append here the list of the few species I collected.

After the Zoological Congress of Padova, we remained a week at San Martino di Castrozza in the Southern Dolomites, in mid-September. The place proved to be very favourably situated for trapping, meadows and forests being before your door and a walk of an hour or two, on well-kept paths, taking you above the tree-line. I took the opportunity of putting out some traps, but found that shrews were much too dominant at that time of the year. Even on the Rolle Pass it was the shrew that sprung the traps instead of the Snowmouse for which the traps were intended. The fleas collected are the same as those taken on former occasions in the more northern Dolomites, with two exceptions. In the article on French fleas a new genus is described which Mr. Cox discovered in France in September; a specimen belonging to that genus was obtained by me at the same time at San Martino di Castrozza, a remarkable coincidence.

I. Moserboden, $2,000 \mathrm{~m}$. (More or Less), August 1930.

1. Ceratophyllus penicilliger Grube 1852.

A small series of both sexes on Microtus sp. and $M$. nivalis.—A very common flea at high altitudes, but equally common down to sea-level.

2. Ctenophthalmus agyrtes impavidus Jord. 1928.

$1 \hat{\jmath}, 3$ $q$, on the same hosts as above.

3. Ctenophthalmus nivalis dolomiticus Jord. 1928.

3 우, on Microtus nivalis._- I obtained 7 specimens of the mouse, with this meagre result. The fleas agree with the examples from the Dolomites.

4. Ctenophthalmus congener Roths. 1907.

1 , on Microtus sp.

5. Leptopsylla bidentatus Kolen. 1863.

1 ô, on Microtus sp._L. sobrinus Roths. 1909 is the same species. 
II. San Martino di Castrozza, 1,450 m. (more or less), September 1930.

1. Ceratophyllus penicilliger Grube 1852 .

A few specimens on Microtus sp. and in a mouse nest.—This nest contained no less than 5 species of fleas.

2. Ctenophthalmus agyrtes impavidus Jord. 1928.

1 ô, 3 우, from mouse nest.

3. Ctenophthalmus congener Roths. 1907.

1 , from mouse nest, 1 \& on Sorex araneus.

4. Rhadinopsylla casta Jord. 1928.

1 , in mouse nest.

5. Doratopsylla cuspis J. \& R. 1915.

A series, on Sorex alpinus and Sorex araneus.

6. Palaeopsylla kohauti Dampf 1910.

A small series, on Talpa caeca.

7. Palaopsylla sorecis Dale 1878.

A series, on Sorex araneus; also below the Rolle Pass at 1,900 m. on the same host.

8. Leptopsylla fallax Roths. 1909.

$2 \hat{\sigma} \hat{\sigma}$, on Evotomys glareolus.—One of the specimens has on one side three genal spines instead of two. A species new for the Dolomites.

\section{Saphiopsylla nupera palina subsp. nov.}

(text-fig. 1).

Close to the + described on p. 229 ; but evidently representing a different subspecies. The row of bristles in front of eye with an additional longish one placed at the ventral margin. Pronotal comb with 23 spines. Apical spines on abdominal tergites : $9,13,11$,

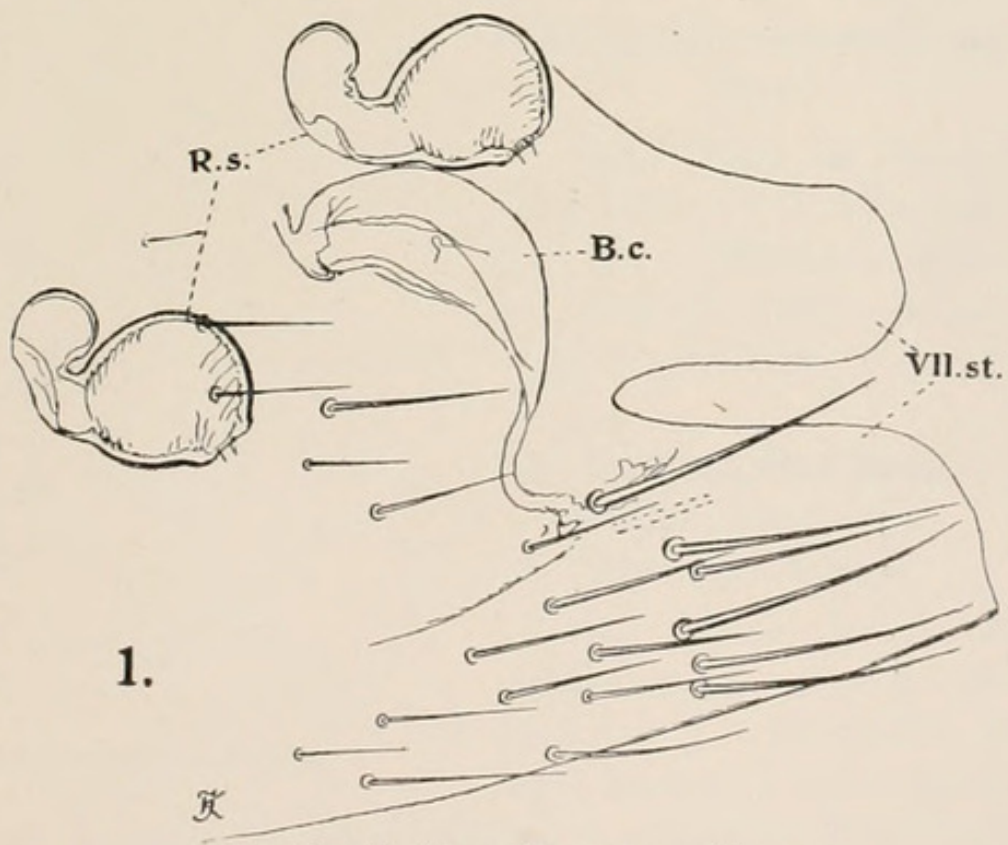

FIG. 1.-Saphiopsylla nupera palina. 7, 5, 2. VII. st. with 48 bristles (the two sides together), upper lobe round at apex, lower lobe more obliquely truncate than in the French specimen. Anal sternite with a bunch of about 15 bristles and on each side a lateral bristle, 
besides the two subapical ones. Below stigma of VIII. t. 4 bristles of which one is long, in the French form no bristle or only one small one; on wide ventral area of this segment (on each side) 25 or 26 bristles on outer surface and 10 on inner. Body of spermathecae distinctly longer than broad.

In mouse nest, 1 q.

\section{Hystrichopsylla talpae Curtis 1826 .}

1 , on Evotomys glareolus.

In the garden of the Zoological Institute at Padova I found a $q$ of Ceratophyllus fasciatus Bose 1801, on Mus musculus. 


\section{$2 \mathrm{BHL}$ Biodiversity Heritage Library}

1931. "Records of fleas from the Austrian Tirol and the Dolomites." Novitates zoologicae : a journal of zoology in connection with the Tring Museum 36, 230-232. https://doi.org/10.5962/bhl.part.10114.

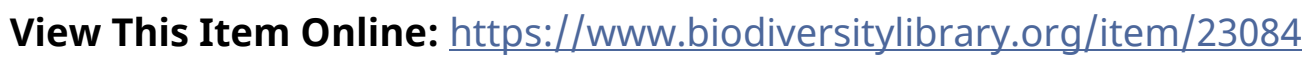

DOI: https://doi.org/10.5962/bhl.part.10114

Permalink: https://www.biodiversitylibrary.org/partpdf/10114

\section{Holding Institution}

Natural History Museum Library, London

\section{Sponsored by}

Natural History Museum Library, London

\section{Copyright \& Reuse}

Copyright Status: In copyright. Digitized with the permission of the rights holder.

Rights Holder: The Trustees of the Natural History Museum, London

License: http://creativecommons.org/licenses/by-nc-sa/4.0/

Rights: http://biodiversitylibrary.org/permissions

This document was created from content at the Biodiversity Heritage Library, the world's largest open access digital library for biodiversity literature and archives. Visit BHL at https://www.biodiversitylibrary.org. 